\title{
Ameloblastic carcinoma of the maxilla: A rare case presentation and a review of new cases
}

\author{
Soudabeh Sargolzaei, Arash Khaleghjoo, Nasim Taghavi* \\ Department of Oral \& Maxillofacial Pathology, Dental School, Shahid Beheshti University of Medical Sciences, Tehran, Iran
}

Received: July 25, 2017

Accepted: October 9, 2017

Online Published: October 15, 2017

DOI: $10.5430 /$ jst.v8n1p15

URL: https://doi.org/10.5430/jst.v8n1p15

\begin{abstract}
Ameloblastic carcinoma (AC) is a relatively rare tumor which accounts for less than $4 \%$ of odontogenic tumors. The mandible is the preferred site and occurrence in the maxilla is extremely rare. Here, we report the case of a 40-year-old male with maxillary AC and present a review of the reported cases from 2009 to 2017 in English literature.
\end{abstract}

Key Words: Ameloblastic carcinoma, Ameloblastoma, Maxilla

\section{INTRODUCTION}

Ameloblastic carcinoma (AC) is an uncommon malignant tumor with aggressive behavior which accounts for less than $4 \%$ of odontogenic tumors. ${ }^{[1]}$ In contrast to ameloblastoma which is well documented, little is known about AC. To date, 92 cases of $\mathrm{AC}$ have been presented in the literature showing its rarity. ${ }^{[2]}$ According to Kruse et al. study, $67 \%$ of ACs are located in the mandible. Maxillary ACs are extremely rare. They reported 26 cases of maxillary AC from 1948 to $2008 .{ }^{[3]}$ Reporting new cases can provide a better understanding of clinical characteristics, biologic behavior and treatment modality of AC.

Here, we report the details of a 40 -year-old male patient with maxillary AC. In addition, the present study reviews the new case reports of maxillary AC in the last nine years (2009-2017) in English literature.

\section{CASe presentation}

A 40-year-old male was referred to the Oral and Maxillofacial Pathology Department, School of Dentistry, Univer- sity of Shahid Beheshti (Tehran, Iran) in June 2016 with a complaint of a painful and rapid growing mass in the right posterior maxilla which was noticed 3 months earlier.Intraoral examination revealed the expansion of the posterior right maxilla, increasing hard palate volume, intact mucosa covering, and firm consistency (see Figure 1). No previous medical history or trauma was detected.

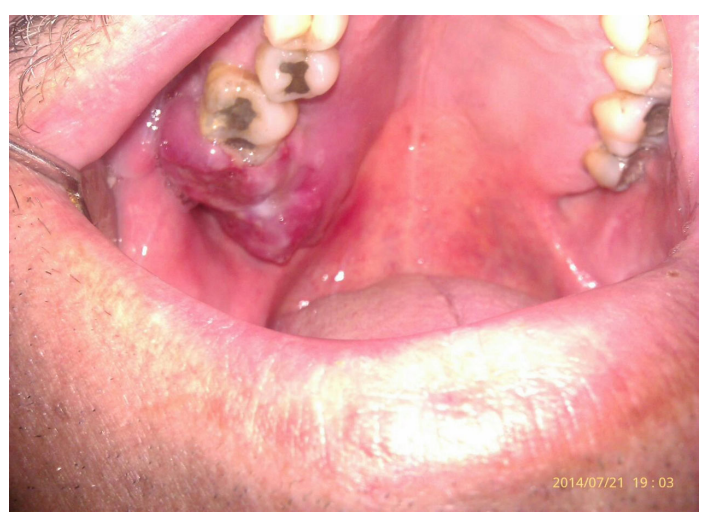

Figure 1. The growing mass in the right posterior maxilla

\footnotetext{
* Correspondence: Nasim Taghavi; Email: nasimtaghavi46@ gmail.com; Address: Department of Oral \& Maxillofacial Pathology, Dental School, Shahid Beheshti University of Medical Sciences, Tehran, Iran.
} 


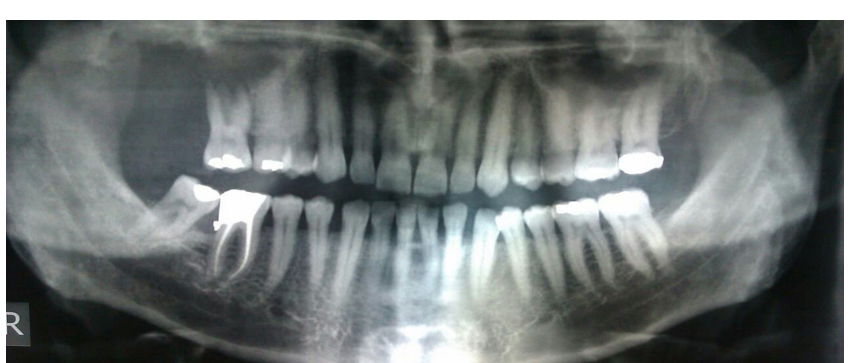

Figure 2. Panoramic radiograph shows an ill-defined unilocular radiolucency in the right posterior maxilla

Panoramic radiograph showed an ill-defined unilocular radiolucent lesion in the posterior area of the maxilla (see Figure 2). On the basis of clinical and imaging findings, a provisional diagnosis of malignant tumor arising from the maxillary bone was made. An incisional biopsy was done and was submitted to oral and maxillofacial pathology service. Gross examination revealed three pieces of irregular creamy brown elastic tissue, measuring $2.2 \mathrm{~cm} \times 1.3 \mathrm{~cm} \times$ $0.4 \mathrm{~cm}$. Microscopically, the sections showed a malignant odontogenic tumor composed of cords, sheets and islands consistent with an ameloblastic lesion. Peripheral palisading of columnar cells, reverse polarized nuclei and stellate reticulum structure were observed in the tumoral islands (see Figure 3). However, evidence of nuclear hyperchromatism, pleomorphism, increased nucleus to cytoplasm ratio and mitotic activity in some areas were found (see Figure 4). These findings suggested a diagnosis of AC. The patient underwent surgical procedure and hemi-maxillectomy was performed. The patient was followed up every two months. After more than a year of follow-up, no evidence of recurrence was observed.
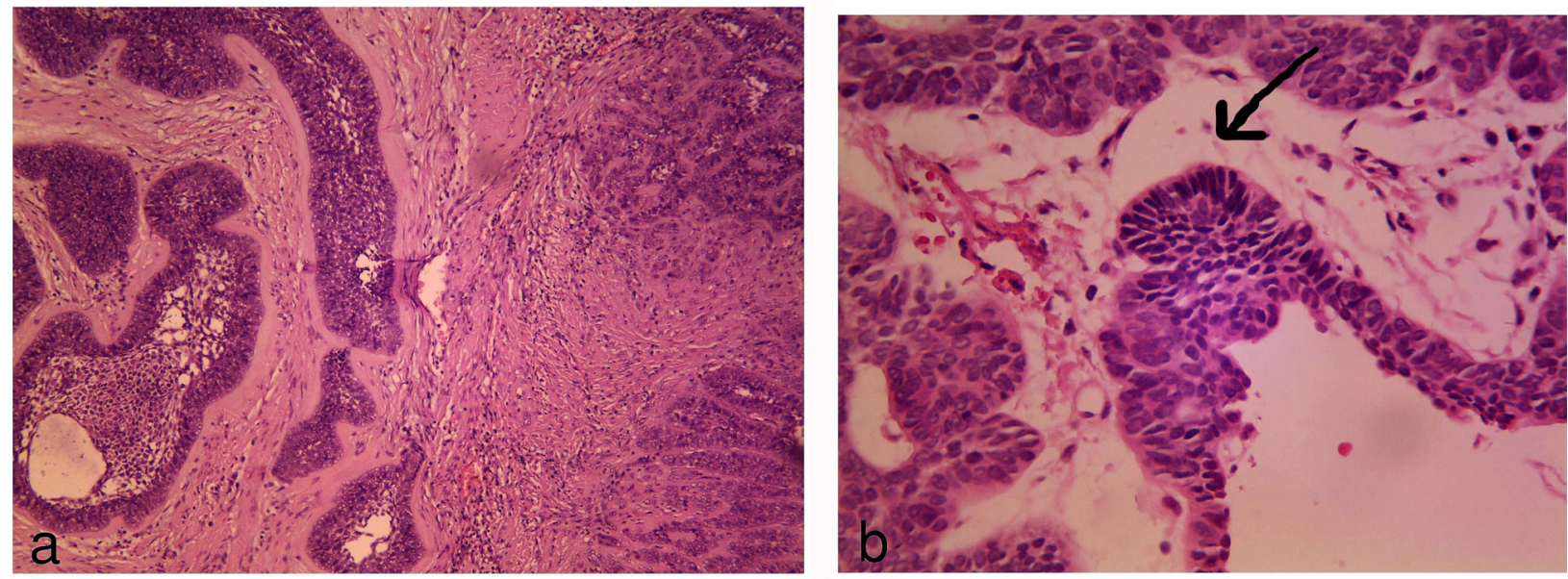

Figure 3. The tumor islands with ameloblastoma features including stellate reticulum structure, peripheral palisading of columnar cell and reverse polarity (arrow) $(100 \times)$
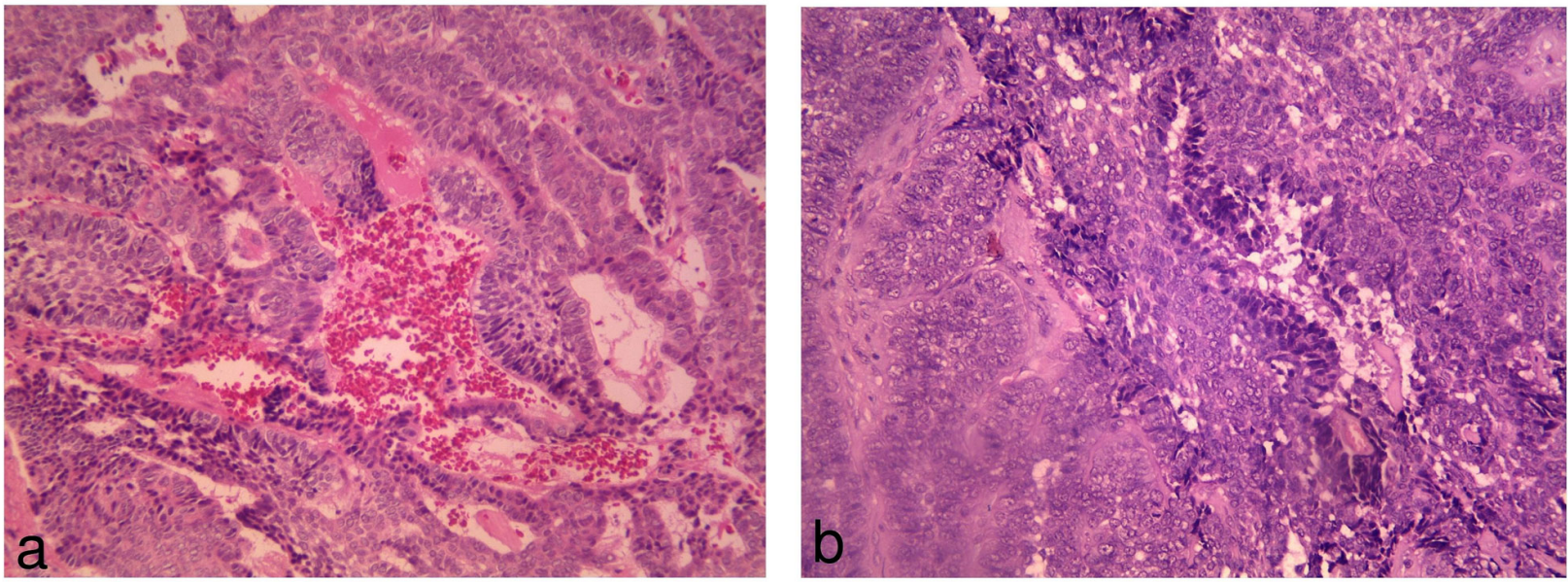

Figure 4. The hyperchromatism, pleomorphism and increased nucleus to cytoplasm ratio in tumor islands $(200 \times)$ 


\section{DisCuSSION}

$\mathrm{AC}$ is a rare malignant epithelial odontogenic tumor which may develop de novo (primary type) or arise within an existing ameloblastoma (secondary type). The underlying mechanism of carcinogenesis in secondary type is not clear. ${ }^{[2]}$ With respect to malignancy, the difference between $\mathrm{AC}$ and malignant ameloblastoma must be considered. The term "AC" must be reserved for an ameloblastoma that has atypical histologic features in the primary tumor, in a recurrence or in any metastatic deposit whereas malignant ameloblastoma is confined to a metastasizing tumor which is a histologically classic ameloblastoma. ${ }^{[4,5]}$ However, some proliferative ameloblastomas or atypical ameloblastomas show increased mitotic index and basilar hyperplasia with insufficient microscopic features of malignancy. In these cases, immunohistochemical markers such as Ki-67 can be helpful. A Ki-67 score $\left(75\right.$ cells/HPF) is an indicator of AC. ${ }^{[2,5,6]}$ According to the literature, $\mathrm{AC}$ affects males more frequently and the predilection age is 50-60 years. Two thirds of the reported cases are in the mandible. Clinically, it appears as a rapidly growing painful swelling. Cortical perforation, trismus and paresthesia are other less frequent clinical features. Metastasis from $\mathrm{AC}$ is found most often in the lung and the cervical lymph nodes are the second most common site for metastasis. $^{[2,4,7]}$

Kruse et al. reviewed 26 cases of maxillary AC over the last 60 years (1948-2008). In the present study, we assessed 17 newly reported cases of maxillary AC from 2009 to 2017 (see Table 1). ${ }^{[2,6,8-13]}$ The age ranges from 21 to 77 years (mean age: 57.1 years) and the male to female ratio was $7.5: 1$, which was consistent with the Kruse et al. report. ${ }^{[3]}$ Most of the lesions (88.2\%) similar to the present case and to previously reported cases occurred in the posterior portion of the maxilla. ${ }^{[7,8,11]}$ Clinically, swelling was the first clinical symptom in $94.1 \%$ of cases. Bleeding, pain, trismus and ulceration were associated with swelling in $47.05 \%$ of cases. Cortical bone perforation, soft tissue invasion and nasal cavity involvement have been documented in previously reported cases. ${ }^{[7,9,12]}$

Table 1. The published cases of maxillary ameloblastic carcinoma (2008-2017)

\begin{tabular}{llll}
\hline Source & Age/Sex & Location & Symptom \\
\hline & $63 / \mathrm{M}$ & Posterior & Swelling, Ulceration \\
Yoon et al.(2009) & $73 / \mathrm{M}$ & Posterior & Swelling, Pain \\
& $61 / \mathrm{M}$ & Posterior & Pwelling, Trismus \\
& $58 / \mathrm{M}$ & Posterior & Swelling \\
Lucca et al. (2010) & $73 / \mathrm{M}$ & Posterior & Swelling, Pain \\
Nicoloti et al. (2011) & $69 / \mathrm{M}$ & Posterior & Swelling, Pain \\
Franka et al. (2012) & $77 / \mathrm{M}$ & Posterior & Swelling, Pain \\
LI et al. (2014) & $59 / \mathrm{M}$ & Anterior & Swelling \\
Uzawa et al. (2015) & $47 / \mathrm{M}$ & Posterior & Swelling \\
Fomete et al. (2016) & $22 / \mathrm{M}$ & Posterior & Swelling, Pain \\
& $55 / \mathrm{M}$ & Anterior & Swelling \\
Loyola et al. (2016) & $32 / \mathrm{M}$ & Posterior & Swelling, Bleeding \\
& $62 / \mathrm{M}$ & Posterior & Swelling, Pain \\
Kar et al. (2016) & $61 / \mathrm{F}$ & Posterior & Swelling, Bleeding \\
\hline
\end{tabular}

Microscopically, AC often retains some histopathologic aspects of ameloblastoma such as inverse nuclear polarization and peripheral palisading in tumoral islands, demonstrating plexiform and follicular patterns, combined with histologic features of malignancy like hyperchromatism, pleomorphism, atypical mitoses, vascular and neural invasion and tissue necrosis. Spindle cell and clear cell-rich variants, and also a few cases with squamous differentiation have been reported. ${ }^{[5,13]}$ Of note, primary intraosseous squamous cell

Published by Sciedu Press carcinoma must be considered in differential diagnosis of AC with squamous differentiation. Granular cell change and extensive clear cell component have been proposed as histologic prognostic indicators of AC. ${ }^{[10,12]}$

With regard to aggressive behavior of AC and the spongy architecture of maxillary bone, the treatment of choice is complete surgical resection with $2 \mathrm{~cm}$ to $3 \mathrm{~cm}$ bony margins. ${ }^{[8,10,14]}$ Despite partial resection and curettage, this approach reduces the recurrence rate by $15 \% .{ }^{[7,9]}$ The effec- 
tiveness of adjuvant radiotherapy is debatable. Importantly, adjuvant radiotherapy in patients with positive lymph nodes, positive resection margins and perineural invasion is suggested. ${ }^{[3,7]}$ Radiotherapy alone for patients with advanced local or metastatic AC or who are not surgical candidate seems appropriate. ${ }^{[7,10]}$ Owing to the small number of cases, elective radical neck dissection is still under review but radical neck dissection for tumors with evidence of positive cervical lymph nodes is recommended. ${ }^{[8,15]}$ To date, few chemotherapy reports for local control are also available that revealed no significant advantages for AC patients. Due to high recurrence rate and pulmonary metastasis, long term follow-up and CT or MRI controls are essential. ${ }^{[16,17]}$

The survival analyses of maxillary AC performed on the 35 cases by Uzawa et al. showed that the five year and 10 year overall survival rates were $83.2 \%$ and $32.3 \%$, respectively. The presence of local recurrence, lymph node and distant metastasis correlated with mortality. ${ }^{[10,17]}$

In conclusion, $\mathrm{AC}$ of the maxilla is rare and predominantly occurs in the posterior area. It is most common in males and in the sixth decade of life. A rapidly growing mass is the most common clinical presentation. However, it may be associated with pain, bleeding, perforation and trismus. Complete surgical resection with clear margins is the most reliable treatment of choice. Radical neck dissection for cases with cervical lymph node involvement is recommended.

\section{CONFLiCTS OF InTEREST Disclosure}

The authors declare that there is no conflict of interest statement.

\section{REFERENCES}

[1] Taghavi N, Rajabi M, Mehrdad L, et al. A 10-year retrospective study on odontogenic tumors in Iran. Indian J Dent Res. 2013 Mar-Apr; 24(2): 220-4. PMid:23965450. https://doi.org/10.4103/09 70-9290.116688

[2] Safadi RA, Quda BF, Hammad HM. Immunohistochemical expression of K6, K8, K16, K17, K19, maspin, syndecan-1 (CD138), $\alpha$ SMA, and Ki-67 in ameloblastoma and ameloblastic carcinoma: Diagnostic and prognostic correlations. Oral Surg Oral Med Oral Pathol \& Oral Radiol. 2016 Apr; 121(4): 402-11. Epub 2015 Dec 17. PMid:26972539. https ://doi.org/10.1016/j.oooo.2015.11 .015

[3] Kruse AL, Zwahlen RA, Grätz KW. New classification of maxillary ameloblastic carcinoma based on an evidence-based literature review over the last 60 years. Head Neck Oncol. 2009 Aug 12; 1: 31. PMid:19674470. https ://doi .org/10.1186/1758-3284-1 $-31$

[4] Avon SL, McComb J, Clokie C. Ameloblastic carcinoma: Case report and literature review. Can Dent Assoc. 2003 Oct; 69(9): 573-6.

[5] Kar IB, Subramanyam RV, Niranjan Mishra, et al. Ameloblastic carcinoma: A clinicopathologic dilemma - report of two cases with total review of literature from 1984 to 2012. Ann Maxillofac Surg. 2014 Jan-Jun; 4(1): 70-7. PMid:24987603. https ://doi .org/10.410 3/2231-0746. 133070

[6] Fonseca FP, de Almeida OP, Vargas PA, et al. Ameloblastic carcinoma (secondary type) with extensive squamous differentiation areas and dedifferentiated regions. Oral Surg Oral Med Oral Pathol \& Oral Radiol. 2016 Jun; 121(6): e154-61. Epub 2015 Oct 13. PMid:26768075. https://doi.org/10.1016/j.0000.2015.09.021

[7] Akrish S, Buchner A, Shoshani Y, et al. Ameloblastic carcinoma: Report of a new case, literature review, and comparison to ameloblastoma. J Oral Maxillofac Surg. 2007 Apr; 65(4): 777-83. PMid:17368379. https ://doi.org/10.1016/j.joms.2005.11 .116

[8] Yoon HJ, Hong SP, Lee JI, et al. Ameloblastic carcinoma: An analysis of 6 cases with review of the literature. 2009 Dec; 108(6): 904-13.

[9] Nicolotti M, Brucoli M, Arcuri F, et al. Ameloblastic carcinoma: Rare localization of a rare neoplasm. J Craniofac Surg. 2011 Nov; 22(6): 2353-5. PMid:22134276. https://doi.org/10.1097/SC S. $0 b 013 e 318231 e 49 b$

[10] França DC, Moreira JM Jr, De Aguiar SM, et al. Ameloblastic carcinoma of maxilla: A case report. Oncol Lett. 2012 Dec; 4(6): $1297-$ 300. PMid:23205126.

[11] Li J, DU H, Li P, et al. Ameloblastic carcinoma: An analysis of 12 cases with a review of the literature. Oncol Lett. 2014 Aug; 8(2): 914-20. https://doi.org/10.3892/ol.2014.2230

[12] Uzawa N, Suzuki M, Miura C, et al. Primary ameloblastic carcinoma of the maxilla: A case report and literature review. Oncol Lett. 2015 Jan; 9(1): 459-67. PMid:25436009.

[13] Fomete B, Adebayo ET, Ayuba GI, et al. Ameloblastic carcinoma of the maxilla: A report of two cases and a review of the literature. J Korean Assoc Oral Maxillofac Surg. 2016 Feb; 42(1): 43-6. PMid:26904494. https ://doi.org/10.5125/jkaoms . 2016.42 .1 .43

[14] Loyola AM, Cardoso SV, de Faria PR, et al. Ameloblastic carcinoma: A Brazilian collaborative study of 17 cases. Histopathology. 2016 Oct; 69(4): 687-701. PMid:27195964. https ://doi .org/10.111 $1 /$ his. 12995

[15] Matsushita Y, Fujita S, Yanamoto S, et al. Spindle cell variant of ameloblastic carcinoma: A case report and literature review. Oral Surg Oral Med Oral Pathol \& Oral Radiol. 2016 Mar; 121(3): e54-61. PMid:26238174. https://doi.org/10.1016/j.00oo.2015.06 .034

[16] Horváth A, Horváth E, Popşor S. Mandibular ameloblastic carcinoma in a young patient. Rom J Morphol Embryol. 2012; 53(1): 179-83. PMid:22395519.

[17] Dhir K, Sciubba J, Tufano RP. Ameloblastic carcinoma of the maxilla. Oral Oncol. 2003 Oct; 39(7): 736-41. https://doi .org/10.101 6/S1368-8375(03) 00036-8 